\title{
Value and politics: introduction to the special issue
}

\author{
Lindsay DuBois $^{1}$ (D) Daniel Salas ${ }^{1}$
}

Accepted: 30 January 2021 / Published online: 11 March 2021

(c) The Author(s), under exclusive licence to Springer Nature B.V. 2021

The papers in this special section address the relation between value and politics ethnographically, across varied locations and spaces. In doing so, they necessarily address the complexity of the concept of value. Our title here is perhaps tautological because value is always about politics. One might argue that "value and politics" is just another way of getting at political economy, for flows of value provide the deeper structure in relation to which classes exist.

Writers of introductions to collections about the anthropology of value struggle to clearly articulate common themes and to define what exactly is meant by value/s and its/their associated processes (cf. Otto and Willerslev 2013). Likewise, for the papers collected here, we cannot offer a common language that glosses the diverse articulations of value. We think this is because the anthropological theory of value, in its best version, offers a holistic framework capable of bringing together the integrated character inherent in the social division of labor. It goes to the core of social relationships which keep people entangled in a given social formation. The specific cases call for highlighting one or another aspect of value and politics, employing the language most relevant to each case.

In thinking about value, it is crucial to continually remind ourselves that value is always about the relations of power that are integral to social life and social reproduction; it describes who produces and who consumes in a certain equilibrium (not to be confused with fairness). Marx makes a distinction between the "real value relation" and "value" (Turner 2008). By "real value relations," he means the proportional allocation of social labor through which a social group sustains itself in the appropriation and transformation of the environment and its members. Value points to how the relational character of such activity becomes represented and understood, and both materially and symbolically organized, in a given society. Power relations produce slippage from real value relations, such

Lindsay DuBois

lindsay.dubois@dal.ca

Daniel Salas

Daniel.Salas@dal.ca

1 Department of Sociology and Social Anthropology, Marion McCain Arts and Social Sciences Building, Dalhousie University, Room 1128, 6135 University Avenue, PO Box 15000,

Halifax NS B3H 4R2, Canada 
that the understanding of those real value relations is distorted (Harvey 2017). As feminists have shown so very clearly with respect to social reproduction, how a given society represents value to itself, as for example with money, has a bearing on what is valued in both economic and moral senses.

The anthropologist who has most clearly articulated the relationship between value and values is David Graeber. Summarizing anthropological value theory, he argues that these different facets of value are organically connected. He writes:

The entire field of anthropological value theory since the 1980s has been founded on a single intuition: the fact that we use the same word to describe the benefits and virtues of a commodity for sale on the market (the "value" of a haircut or a curtain rod) and our idea about what is ultimately important in life ("values" such as truth, beauty, justice), is not a coincidence. There is some hidden level where both come down to the same thing (Graeber 2013, 224).

Graeber goes on to comment that the division is an artefact of the commoditization of labor. The money form marks the distinction between the two. The value of something can be put in dollar terms, but values cannot—or ought not to- have a price attached. The money form, in its circulation marks the frontier between what has been commodified and what remains outside the commodity relationship. That frontier is moving, contested, and the product of political operations. Taken as a whole, the papers collected here elegantly illustrate these interconnections.

It takes effort to keep in mind the wholeness of value because we think of values (what is important and what is good) as separate from the exchange price of things, and often as contrary to it. As anthropologists in the political economy tradition, we tend to assume that class interests often determine values. The conventional understanding for a long time has been that as market forces advance into previously non-commodified realms of life, money-based valuing practices drive out other ways of attributing value. The implication of this was that values belonged to some non-capitalist traditional space, and had a harder time coming back to shape the economy-for example in arguments about the commodification of everything. Many scholars, including the anthropologists in this collection, complicate this implicit teleology. As their work shows, values continue to matter politically as they are put to work hand in hand with more strictly economic forces to accomplish certain political-economic ends, but also as they interrupt the supposedly triumphant march of commensurability and commodification. For example, in the neoliberal project, as Cooper (2017) has recently argued for the US case, the advance of the market-individualist ethos was from the very beginning underpinned by normative campaigns to redefine the family and its private debt obligations, rather than the institutions of the welfare state, as moral foundations of the new order. Further, there are times and places where values like the prioritizing of the individual undermine economic goals of those same neoliberal actors. We need look no further than the current mask controversy: the individual freedom not to wear a mask in context of Covid-19 is prioritized at the expense of the economic activity which neoliberals theoretically prize above all. 
Anthropologists have noted three main aspects of value described across disciplines which try to study it: first, a moral aspect related to what is good, proper or desirable in human life; second, an economic aspect understood as consumer demand; and third, as meaningful difference in the linguistic sense (Graeber 2001). Graeber points out that none of these understandings is sufficient unto itself and proposes a synthesis by defining value as "the way people represent the importance of their own actions to themselves: normally, as reflected in one or another socially recognized form" (p. 47). In this sense, the value-importance of a given product or social institution would correspond to the proportion of a society's creative energy invested into producing and maintaining it. This approach sees value as essentially meaning created in action. Things as different as birthdays, traditions, or pharmaceutical developments can arguably be considered in these terms.

The articles in this collection operationalize and employ value and values in myriad ways because they address specific instances in which the politics of value come to the fore. Authors in this collection refer to value, values, valuation, regimes of value, commodification, currencies, calculation, and incalculability. The variety of terms and emphasis speak to more local and concrete balances of force and of class formations in very concrete terms, notwithstanding their location in a global architecture of value which is the capitalist world system. Perhaps most striking in the contributions here is the way the different senses of value converge at one point or another.

Such a convergence is very much in evidence in Catherine Dolan, Juli Huang and Claire Gordon's investigations into "mutuality," the corporate value at the center of Food Co's "values-based management" approach. Their examination sheds light on how corporations try to (or perhaps only claim to) decenter profit-making, prioritizing corporate values instead. The careful study of what mutuality means within the company across a range of social positions and geographical locations ranging from the UK to Kenya, reveals that "mutuality" has staying power precisely because of its ambiguity - a concept they explore in some detail here. The authors conclude that, although executives might not understand this process, ambiguity around their corporate keyword allows Food Co to "paper over the cracks between sharing values and sharing value." An intriguing aspect of this case is that the corporation sought collaboration with researchers in its quest to more clearly define mutuality. In light of Graeber's argument that value can be calculated while values appear to defy such calculus, it is striking that the executives at Food Co. are intent on defining, quantifying and finding a metric of mutuality in their organization, a task at which they had not yet succeeded. Still, their corporate value of mutuality serves as a "tangible cultural asset" which helps position the firm in the marketplace.

While Dolan, Huang, and Gordon highlight the incalculability of the quality of mutuality for Food Co, Oana Mateescu's article about a Romanian forest commons focuses on the marvels and progressive possibilities of calculation. Her work seems especially timely in light of the recent emphasis on the commons, and the commoning movement as a model for alternative economic arrangements. Mateescu's historical ethnography explains distribution operations of the forest commons of Vrancea, Romania. Counterintuitively perhaps, Mateescu argues that impressive acts of calculation, including popular mathematics and "distributive repair" are essential to 
making the commons work, and therefore to sustaining them, to a greater or lesser degree across several centuries and in the context of various attempts at encroachment. Her article is a critique of romantic visions which see the commons as innocent of calculation; she shows that, while the commons were indeed rendered calculable, other considerations of value made this process open-ended, malleable and resilient.

Daniel Salas's concept of "incalculability" offers another take on quantification and its limits. His examination of Cuba's double-currency system reveals more clearly than usual some of the peculiar qualities of money as a fiction which purports to represent value. In the Cuban context, two currencies are tied albeit imperfectly to two different value systems: the regular peso is tied to social reproduction and the revolution, while the convertible peso, pegged to the U.S. dollar, comes from connections with the outside capitalist world. Salas describes for us the awkward way in which these two spheres of value/values coexist, and how that coexistence requires incalculability. His account offers a striking illustration of how the economic rationality of the system has been sacrificed to maintain the hegemonic construction of what the ruling class sees as socialist values.

Bodirsky brings the concept of hegemony to the fore in her description of how hegemonic projects employ what she calls "modes of valuation" to stitch together diverse groups in the context of recent Turkish authoritarian populism. She unpacks how these modes produce not just a moral community or inside, designed to foster necessary strategic alliances, but also an outside whose members are devalued and dispossessed. Following Gramsci (2000), she uses hegemony as a way of thinking about the combination of the economic and ideological (she uses the term "ethicopolitical") aspects of value not only with regard to the value of commodities but also of persons. In this case construction becomes a lynchpin of the hegemonic alliance, tying together capital, foreign investment, ideas of modernity, with the prospect of employment and modern housing. In Bodirsky's analysis, the more economic sense of value and the moral one do not so much intersect as complement each other. Class and economic projects, although crucial, are not sufficient to explain what is going on and how. The Turkish regime also needs moral Others, defined in ethnic or religious terms, for its project to work.

Infrastructure and state services also lie at the heart of Kristen Francescone's article about small-scale miners in Potosi, Bolivia. In this case, crumbling hospitals and failing healthcare are signs of neglect with larger political consequences. Francescone shows how limited but important experiences of visiting Cuban healthcare workers make a startling contrast to the truly awful healthcare which miners and their families receive in both public hospitals and private clinics. For Francescone, the humane treatment from the Cuban (or Cuban-trained) doctors offers a practical critique of capitalist health care, a critique which in turn becomes a key feature of miner demands in political mobilizations and a dramatic strike. The healthcare issue is important because it is literally a matter of life and death, but also because it underlines the ways in which miners are "perceived as merely commodities" as Francescone argues. In these contrasting types of healthcare, the miners see different values and ways of valuing them. The "trato humano" by Cuban doctors lays bare how miners are typically treated as things, valued as factors of production. The 
egalitarian approach of Cuban doctors is predicated on a different value system characterized as humanist and anti-capitalist.

The role of the state is also a central preoccupation of Argentines receiving conditional cash transfers in Lindsay DuBois's contribution. She examines how value, in its money form, shapes and is shaped by moral discourses and political contests. Her case shows how money's qualities of anonymity and fungibility lead to specific kinds of challenges and conflicts. A particularly noted quality of the money form is its fungibility, meaning the capacity to seamlessly convert one thing of value into another. Money is also anonymous, such that no one ever really knows whose money ends up where. The ideal of money's fungibility and anonymity work together defining a space for contention in which recipients, state and non-recipient middle classes try to fix the meaning of the cash transfer in ways that advance their political interest and personal status. Cash payments are celebrated as less political, more efficient, and perhaps more just than other forms of social assistance. In a surprising turn of events, the anonymity and fungibility of cash payments has proven fraught because these very qualities become a blank canvas onto which these different constituencies project their resentments and moral critiques.

As these articles amply demonstrate, the analytics of value lend themselves to nuanced critiques of what comes to matter in the context of specific political and economic formations. They allow us to think about the connections between these struggles over livelihoods and appropriation, on one hand, and the always challenging task of building meaningful lives in common, on the other.

\section{Declarations}

Conflict of interest The authors declare no competing interests.

\section{References}

Cooper, Melinda. 2017. Family values: Between neoliberalism and the new social conservatism. New York: Zone Book.

Graeber, David. 2001. Toward an anthropological theory of value: The false coin of our own dreams. New York: Palgrave.

Graeber, David. 2013. It is value that brings universes into being. HAU: Journal of Ethnographic Theory 3: 219-243. https://doi.org/10.14318/hau3.2.012.

Gramsci, Antonio. 2000. The Gramsci reader: selected writings, 1916-1935. New York: NYU Press.

Harvey, David. 2017. Marx, capital, and the madness of economic reason. London: Profile Books.

Otto, Ton, and Rane Willerslev. 2013. Introduction: "Valueastheory": Comparison, culturalcritique, andguerillaethnographictheory. HAU: Journal of Ethnographic Theory 3: 1-20. https://doi. org/10.14318/hau3.1.002.

Turner, Terence. 2008. Marxian value theory: An anthropological perspective. Anthropological Theory 8: 43-56. https://doi.org/10.1177/1463499607087494.

Publisher's note Springer Nature remains neutral with regard to jurisdictional claims in published maps and institutional affiliations. 